\title{
Qualitative Formaldehyde on Analysis of Tofu at Traditional Markets in Banjarmasin 2019
}

\author{
Melviani ${ }^{1}$, Chanti Jessica Ravani ${ }^{2}$, Indra Nopian ${ }^{3}$, Mahdiaty $^{4}$, Rhahimah $^{5}$, \\ Vina Amrina ${ }^{6}$ \\ \{melviani@unism.ac.id\}
}

Sari Mulia University, Jl. Scout 2, PemurusAffairs. District. East Banjarmasin, Banjarmasin, South Kalimantan, 70 238, Indonesia

\begin{abstract}
The purposeofthis study is to Determine the content of formal dehyde as a preservative tofu on the whichistraded at a traditional market in Banjarmasin (Firmarket, Pal 6 market, Modestmarket, Pal 7 market, and Kasturi market). The sampling process in each markets was three times; they were in the front, the middle and the back of the market. Then, the samples were Analyzed qualitatively. The findings Showed that $80 \%$ of tofu traded did not contain formal dehydeand $20 \%$ of tofu contained formal dehyde. Moreover, the result of this research that the tofu producers interpreted in Banjarmasin still used formaldehyde as a preservative in the process of creating tofu, In conclusion, the implications of this research are: hopefully, the findings can be used as a reference to customers for buying tofu the which is traded in traditional markets in Banjarmasin and it is Necessary to discover natural ingredients roomates are cheap, effective and efficient for substitute the function of formalin.
\end{abstract}

Keywords: Tofu, Formalin, Traditional Markets.

\section{Introduction}

Abuse of harmful chemicals as additives for food and beverage products that are not in accordance with the allocation has made many people uneasy. The use of chemicals such as dyes and preservatives for food or foodstuffs made by producers to dairy products become more attractive, more durable and more economical of course also expected to generate a profit as much as possible. But the health effects arising from the use of hazardous materials are very bad for the people who consume them. Acute food poisoning as well as the accumulated effects of chemicals that are carcinogens are some health problems that will be faced by consumers [1].

Tofu is a food made from soy beans are finely ground white, boiled, separated between the pulp and filtrate, then given extra vinegar. Tofu is one food source of protein consumed by many people. High content of vegetable protein in tofu is considered to replace animal protein. Behind these advantages, know not necessarily safe to be consumed continuously. Tofu is a food product that is vulnerable to damage it is not rare tofu products such as formaldehyde preservatives added to make it more durable [2].

Formalin is a solution that is colorless, has a strong smell, and contains $37 \%$ formaldehyde in water[3]. Formalin is not allowed in food or drink, because in the long term 
can lead to the development of cancer cells, respiratory tract irritation, allergic reactions, and burns. One of the foods that are often added formaldehyde is know[4]

According to the Ministry of Health (Menkes) No. 33 of 2012 on Food Additives, formaldehyde is a chemical whose use is prohibited for food products. Formalin for health hazard if swallowed then the mouth, throat and stomach burning, pain when swallowing, nausea, vomiting and diarrhea, severe abdominal pain, headache, hypotension. It can also be damage to the liver, heart, brain, spleen, pancreas, the central nervous system and kidneys. The main hazard if swallowed formalin and the impact can be a cancer hazard to humans because it is carcinogenic.

Formalin is a solution that is colorless and smells very piercing. In about 37 percent formalin contained formaldehyde in water. Formalin is often used as a disinfectant, insecticide materials, industrial raw materials of plastic and is also used in various industries such as textiles, pharmaceuticals, cosmetics and is used to preserve dead bodies [5].Formalin is one type of preservative that is often misused and is legally forbidden used to preserve food products. Ironically, formalin is very easy to find with the price is cheap, so it is often used by manufacturers and traders know to preserve their products. This causes restlessness and anxiety in the community considering the side effects of formaldehyde consumption can harm health [6]. Therefore we are interested in doing the analysis and identification of the content of preservative formalin know who traded in some traditional markets in Banjarmasin.

\section{Research Methods}

\subsection{Materials and Equipment}

Samples know coming from traditional markets $(\mathrm{T})$ in circulation in Banjarmasin, 0.1 $\mathrm{N} \mathrm{KMnO} 4$ solution, distilled water and filter paper.The tools used in this study a glass tools such as test tubes, beakers, pipette, stir bar. filter funnel and tube rack.

\subsection{Research procedure Qualitative analysis of formaldehyde content}

This analysis uses two test tubes each coded A and B. A test tube filled with $2 \mathrm{~mL}$ of distilled water, then add 1 drop of $0.1 \mathrm{~N} \mathrm{KMnO} 4$ solution and stirred until homogeneous. B test tube filled with $10 \mathrm{~mL}$ of distilled water, and then added $5 \mathrm{~g}$ sample out. Then stirred until homogeneous, and filtered to take the filtrate. The filtrate out from the test tube B is inserted into a test tube A. Settling to 30 minutes. Observed color changes. If the faded pink color, indicating the sample contains formaldehyde.

\section{Results and Discussion}

Samples were analyzed were 10 samples taken from six locations, namely Kasturi Market, CemaraMarket, Kalindo Market, Morning Market, Pal 6Market, and SederhanaMarket. Analyzes were performed with potassium permanganate test[7].

Table 1. Test Results Color using KMnO4

\begin{tabular}{|l|l|l|l|}
\hline No. & Samples & Discoloration & Result \\
\hline
\end{tabular}




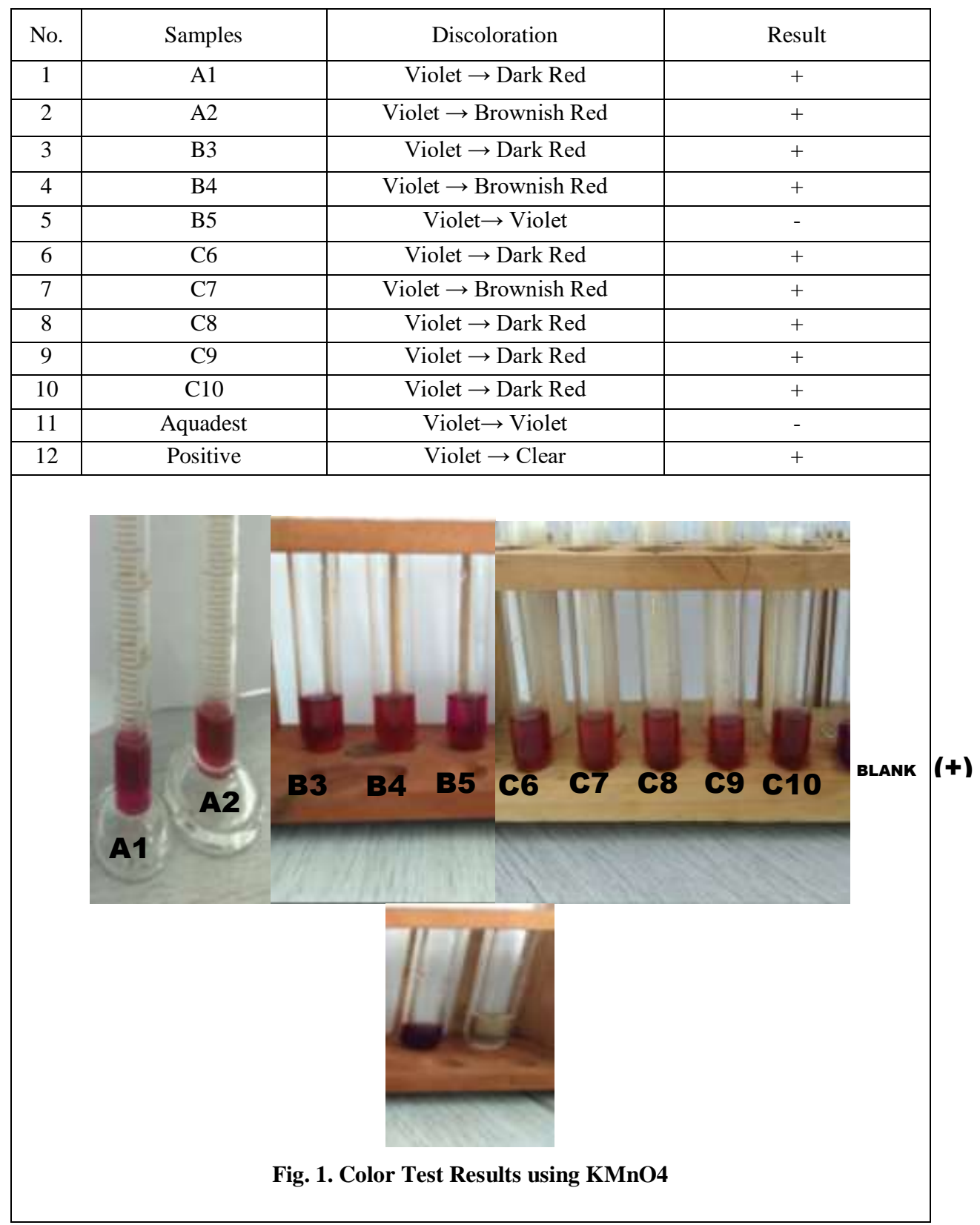

From the observation of color (Figure 1 and Table 1) qualitative test was conducted by the addition of potassium permanganate [7]. The principle of this test is to know which sample was dissolved in aquadest added a solution of potassium permanganate. The addition of $\mathrm{KMnO} 4$ (potassium permanganate) function to oxidize formaldehyde in formalin, which is characterized by loss of the pink color to colorless (clear). The loss of a pink color on the sample indicates a positive sample containing formaldehyde[8].Potassium permanganate is a 
strong oxidizing agent that can oxidize formaldehyde contained in the formalin which is characterized by the loss of potassium permanganate color within the specified time after the test tube containing the sample shake.[9]states all the aldehydes can be oxidized to the carboxylic acid with a reagent $\mathrm{KMnO} 4$. If the color soon faded / missing means foodstuffs containing aldehyde of this study is to reduce potassium permanganate. The results obtained from the identification of formaldehyde in 10 samples out using potassium permanganate solution, 9 of them showed positive results. This is indicated by a color change of the solution of potassium permanganate which was originally a violet fading into dark purplish-red and the color does not change back for 60 minutes after reacting with the sample. When compared with the blank, samples significant changes color to red. This means that 9 samples out circulating in the market turns positive Banjarmasin contain formaldehyde. Therefore we need a further quantitative test to determine the amount of formaldehyde content of each knew that, but the researchers did not do a further test it.

\section{Conclusion}

Based on the results and discussion, we conclude that from a qualitative test 10 samples out using potassium permanganate solution, 9 of them showed a positive.Hal is indicated by discoloration of potassium permanganate solution which was originally a violet fading into dark purplish-red and the color does not change back for 60 minutes after reacting with the sample. This means that 9 samples out circulating in the market positive Banjarmasin contain formaldehyde.In further research is recommended to test the quantitative formaldehyde in samples containing formalin out positive so that it can be known how much the concentration of formaldehyde contained in the tofu.

\section{References}

[1] Aghnan. preservatives and flavoring in food (borax, formaldehyde, AND MSG) (https:// aghnan354.wordpress.com/science/materials-and-flavoring preservative-in-food-borax-formalinand-msg /). Retrieved on May 7. (2016).

[2] Puspasari, G., and Hadijanto, K. The Quality Test Formaldehyde in the Yellow Know the Market "X" in Bandung. Maranatha Christian University. Bandung. (2014).

[3] Uddin R., Wahid MI, Jesmeen T., Huda NH, Sutradhar, KB. Detection of Formaldehyde in Fish Samples Collected from Dhaka City, Bangladesh. SJ Pharm. Sci. 4 (1). 49-52. (2011).

[4] Nelly. Qualitative Analysis Formaldehyde Content in the Know Sold in Market Traditional market in the district and sub district of Medan Area Medan Tembung. http://repository.usu.ac.id/handle/123456789/31027 (downloadable on May 7, 2019). (2011)

[5] Service bulletin, Edition January. No. 73 / Year VII. Formalin Not a Formality. (2006).

[6] Ariani Novia, Safutri Maida, and Musiam Siska. Formalin. Qualitative Analysis on Raw DijualdDi Know Kalindo Markets, Gulf oysters Dan telawang Banjarmasin. Banjarmasin: Academy of Pharmacy ISFI Banjarmasin. (2016).

[7] Amir A. Identification of Formaldehyde in Wet Noodle Products and Qualitative Methods Tofu with KMnO4 solution. journal Tasimak. (2011).

[8] Moffat, AC. Clarke's Isolation and Identification of Drugs.2 nd Edition. London. The Pharmaceutical Press. Translation: Ngadiwaluyo and Suharjito 2003. (1986).

[9] Fessenden and Fessenden. Organic Chemistry. Jakarta: Erland. (1997 